\title{
INCREASING ORGANIZATIONAL CITIZENSHIP BEHAVIOR THROUGH QUALITY OF WORK LIFE AND ORGANIZATIONAL COMMITMENT
}

\author{
Endang Susilawati \\ Shofia Amin* \\ Musnaini \\ Universitas Jambi, Indonesia
}

\begin{abstract}
This study aims to examine the effect of Quality of Work Life on Organizational Citizenship Behavior through Organizational Commitment as a mediating variable. The population in this study were all permanent employees of PT. Petro China International Jabung Ltd with a sample of 120 respondents. The data collection method uses questionnaire method which is measured using Likert scale and the hypotheses was tested by using the PLS (Partial Least Square) program. The results showed that the quality of work life has positive and significant effect on Organizational Citizenship Behavior, the quality of work life is proven to have positive and significant effect on organizational commitment, organizational commitment has positive and significant effect on Organizational Citizenship Behavior, and organizational commitment partially mediates the relationship between the quality of work life and Organizational Citizenship Behavior. The implication of this research is that the increasing quality of work life will increase organizational commitment so that it can improve Organizational Citizenship Behavior. The company must continuously improve the quality of work life program to increase the employee performance with objective and systematic procedures.
\end{abstract}

Keywords: Quality of Work life, Organizational Commitment, Organizational Citizenship Behavior,

\footnotetext{
*Corresponding author. Email address: shofia.mgt@gmail.com
}

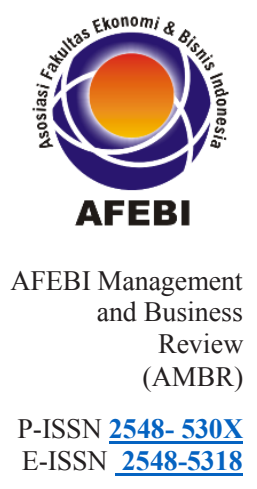


Organizational citizenship behavior (OCB) is a unique aspect of individual activity at work. Tambe and Shanker (2014) explained that OCB is the behavior of employees at a time which shows certain behaviors that go beyond the employee's duties. OCB is a form of behavior that is an individual choice and initiative, not related to the organization's formal reward system but in aggregate to increase organizational effectiveness (Marlina, Wulandari \& Ramashar, 2020). In line with Saepudin and Djati (2019) explained that OCB is the freedom of individual behavior, which is indirectly or explicitly recognized by the reward system, and contributes to the effectiveness and efficiency of organizational functions. This statement shows that OCB is not included in the job requirements or formal job descriptions of employees so that if it is not displayed it will not be sanctioned by the company but as a whole it can affect the effectiveness of the organization, so it also explains that the company will be successful if its employees do not only do it. main task, but also willing to do extra tasks, such as willing to cooperate, provide advice, help to help, participate actively, and willing to use his work time effectively. The statement regarding the importance of organizational citizenship behavior was also put forward by the research of Traiyotee, Taeporamaysamai and Saksamrit (2019), OCB behavior is very important for employees in the company because having extra role behavior means that employees can serve and be dedicated to work, which projects a positive effect on the success and welfare of the company. This is also reinforced by a statement of Robbins \& Judge (2016) which states that companies that have employees with a high level of organizational citizenship behavior will show better performance and ultimately contribute more to the achievement of organizational goals.

Rosario, Marquez, Zayas and López (2020) explain that OCB is considered important and valuable for the survival of the organization. OCB can increase both coworker and managerial productivity, besides that it can increase the efficiency of the use of organizational resources, stability of organizational performance, increase the ability of organizations to adapt to changes in the business environment, and become an effective basis for coordination activities between team members and between work groups. If OCB does not materialize in the organization, it will result in when the organization requires the energy and thoughts of employees outside their role, the organization will encounter difficulties so that in the end the organizational goals cannot be achieved properly (Aini, Hardjajani \& Priyatama, 2014).

Recognizing the importance of the influence of organizational citizenship behavior in improving employee performance and contributing to the achievement of organizational goals. Aisyah and Wartini (2016) said that OCB's employee can be influenced by several factors, including the quality of work life and organizational commitment. Suriyana, Wijaya and Kumbara (2020) in their research also states that the OCB that will support the success of the company is also influenced by the quality of work life. In line with research from Kurniawati (2018) that employees who have a high quality of work life will encourage actions taken by employees that exceed the minimum requirements expected by the role of the company and promote the welfare of colleagues, work groups, and the company. Therefore, of course, the organization needs to create a quality work life within the company because this factor has an influence on the emergence of positive behavior among employees, one of which is the behavior that shows the organizational citizenship behavior. Srivastava, Misra and Madan (2019) in their research states that improving the quality of employee work life is very important for companies to improve performance and productivity. The positive results of implementing this quality of work life include a reduction in work fatigue, a reduction in absenteeism and turnover and an increase in organizational commitment.

Companies that have high quality of work life ultimately lead to more sustainable efficiency, productivity and profitability (Mebarki, Fouatih \& Mokdad, 2018). The description above explains that the quality of work life is an important problem for organizations to achieve competitive advantage, this is due to the view that the quality of work life is considered capable of increasing the role and contribution of organizational members. With the implementation of the optimal quality of work life in the company, it is hoped that it will be able to encourage the OCB or the extra role behavior of employees in the company.

Apart from the quality of work life, the next variable that affects organizational citizen behavior is organizational commitment. Organizational commitment is an important behavioral dimension that can be used to assess the tendency of employees to stay as members of the organization. Commitment is the identification and connection of a person who is relatively strong in the organization. The study of Widodo, Sunaryo \& K. (2019) found that high organizational commitment has different attitudes than those with low commitment. Organizational commitment behavior results in work performance, low levels of absenteeism and low levels of employee turnover. So that with a high commitment within employees, it increases awareness that what is done solely for the company has a direct impact on its performance. In other words, the employee's organizational commitment will be able to hold himself back from moving to another company so that it can reduce the turnover cost of a company and also maximize his work in that one company. 
In line with the statements of Maghfironsyah and Yuniawan (2019) that when someone has a strong commitment to their organization, that person will try their best to give their best in order to survive in the organization and will also have a good impact on the organization, and the level of loyalty of its members will be. is automatically formed and tends to be high. Vice versa, if someone has a commitment that is considered or felt to be lacking, then the level of loyalty will also be less and even tend to be low. Thus, the higher the employee's commitment to the organization, the emotional relationship between the employee and the company will indirectly. This statement is supported by Gunastri et al., (2019) explaining that employees who have organizational commitment will carry out tasks that are not only tasks that have become their obligations according to existing jobs, but also do other work (extra role), where if There are employees who are not able to do a job, then this committed employee will tend to help his colleagues to achieve the goals expected by the organization without comparing their abilities with other employees. Organizational commitment in this study is used as a mediating variable in creating extra role behavior (OCB) in the organization.

Employee work patterns at PT. PetroChina International Jabung Ltd is very interesting to study, because employees have an uniqueness that distinguishes them from employees of other organizations, namely organizations with various educational backgrounds, various skills, and different job characteristics, thoroughness, technological literacy, and various skills. From the various backgrounds, each plays a different role. When employees play a role in accordance with the demands of their duties and responsibilities, it is called in role behavior. However, sometimes jobs at PT. Petro China International Jabung Ltd cannot be completed in one work unit alone, and cross-unit cooperation is required. For example, in the Maintenance and Operations work unit, staff can help each other with the smooth running of work because of limited human resources and the demands of work to be completed on time as scheduled, they can even do work outside of their duties beyond the perception of their role. This behavior phenomenon is often referred to as organizational citizenship behavior, or the extra-role behavior". Research results from Novelia et al., (2016) explain that employees with high OCB behavior will increase their productivity and success in an organization. The statement regarding the importance of organizational citizen behavior is also supported by research by Prasetio (2016) which states that organizations that have employees with high levels of OCB will be more effective and run smoothly because employees have good social bonds and in the end the organization will have higher performance.

The role of employees in PT. Petro China International Jabung Ltd must pay attention to the quality of its work, with employees having extra role behavior, of course it can increase work productivity. Extra role behavior has a role to be able to improve the bad side of employees who do not want to cooperate among employees considering that this company requires good cooperation between employees in completing their work. As in the condition of employees whose jobs are not too dense, they can help other employees who are in trouble in their work that is already pressed for time. Based on the results of preliminary interviews conducted by researchers on several employees at PT. Petro China International Jabung Ltd can be seen that the role of workers in helping colleagues who have problems at work is still lacking. This can be seen in Table 1 below:

\begin{tabular}{lcl} 
No Number of people & \multicolumn{1}{c}{$\begin{array}{c}\text { Problems from employees } \\
\text { Employees do not want to help their co-workers because } \\
\text { these employees feel they have their respective duties and } \\
\text { also the lack of these employees in interacting with } \\
\text { fellow co-workers } \\
\text { Employees often complain when given additional tasks } \\
\text { by the leadership } \\
\mathbf{3}\end{array} \mathbf{E}^{\text {Employees are often lazy while working }}$} \\
$\mathbf{4}$ & 4 & $\begin{array}{l}\text { Employees often ignore or are not interested in the } \\
\text { activities carried out by the company }\end{array}$
\end{tabular}

Total 16

Source: Survey, 2020

\section{Increasing \\ Organizational \\ Citizenship \\ Behavior Through \\ Quality of Work \\ Life and \\ Organizational \\ Commitment}

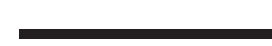

Table 1 shows that there are several employee problems working at PT. Petro China International Jabung Ltd, which can be said that workers have OCB levels is still quite low. The table above shows 7 out of 16 people do not want to help their coworkers because these employees feel they have their respective duties and also the lack of these employees in interacting with fellow colleagues, 3 out of 16 often complain if they are given additional assignments from company leaders, 4 out of 16 people employees are often lazy in carrying out their duties in the company, and 2 out of 16 people often ignore or are not interested in activities or events carried out by the company. Seeing the low OCB in this company, it is necessary to find the root cause of the low level of OCB at PT. Petrochina International Jabung Ltd. This low level of OCB can have negative impacts on the company, such as reducing the productivity of colleagues, reducing managerial productivity, and reducing the efficient use of organizational resources (Belwalkar et al., 2018). 
From the description of the phenomenon above, it can be concluded that companies really need the support of competent human resources or workers who have a loyal attitude towards their organization so that the company's goals can be achieved. The results of research from Syahbanuari and Abdurrahman (2019) explain that to achieve the desired level of organizational citizenship behavior, every organization must pay attention to, including the quality of work life and organizational commitment of each employee. Therefore, to overcome the problems revealed above, where employees are faced with a number of large duties and responsibilities as well as guidance on their professional roles, and on the other hand the lack of employee characteristics in helping fellow colleagues voluntarily, therefore extra behavior is needed. the role of the employees of PT. PetroChina International Jabung Ltd which is known as Organizational Citizenship Behavior.

\section{LITERATURE STUDY}

\section{Organizational Citizenship Behavior}

The concept of OCB was introduced firstly by Organ et al in the 1980s which was re-updated in 2006. Shahin et al., (2014) stated that Organizational citizenship behavior is individual behavior and, because of its optional nature, has not defined directly in formal reward systems in organizations, doing so leads to increased effectiveness and efficiency of organizational performance. In connection with this statement, Hermawati \& Mas (2016) also explained that OCB arises because of feelings of being a member of the organization and feeling satisfied if they can do something more to the organization. Likewise, Putra et all, (2018) stated that OCB is the behavior of employees who work outside the job desk but provide benefits to the company or in other words employee voluntary behavior that helps organizational productivity. The company hopes that employees must be able to do the assigned tasks even though they are not the main task, where employees will get feedback if they are able to make a positive contribution to the company. The literature was established that there are five dimensions of OCB, namely (1) Altruism, (2) Civic Virtue, (3) Sportmanship, (4) Conscientiousness and (5) Courtesy (Organ, 1980).

\section{Quality of Work Life}

The concept of quality of work life was originally born in 1972 since the industrial revolution and the formation of labor unions. The trade union held the first international labor conference and produced a concept of quality of work life (Golkar, 2013). In his research, Rahman (2017) explained that the quality of work life (QWL) was applied for the first time to formulate that every initial process decided by the company is a response to what their workers want and hopes are, this is realized by discussing problems and uniting their views (company and employees) into in the same goal, namely improving the performance of employees and the company.

Basically, the quality of work life can be concluded as a concept that talks about three things: 1). Meeting the personal needs of employees, 2). There is authority in determining work, and 3). There is satisfaction in the environment and employee work. From these three things, it can be interpreted that the quality of work life is a concept that talks about the welfare of employees at work. The quality of work life means the extent to which the employees live in the organization in the environment in which they work (Rahman, 2017).

In contrast to Avianti \& Kartika (2017), in their research using the Cascio concept by using nine indicators in the application of the quality of work life, namely: (1) Safety of the work environment (save environment), (2) Equitable compensation, (3) Communication, (4) Conflict Resolution, (5) Career development, (6) Employee participation, (7) Job security, (8) Facilities available (Wellness) and (9) pride in the institution (Pride).

\section{Organizational Commitment}

Sarhan et al., (2019) explain that organizational commitment is defined as the relative strength of the identification of individuals with and involvement in a particular organization, the individual has a strong belief in and approval of the principles and goals of the organization, the willingness to apply more energy to the work of the organization, and want to remain as a member in the organization. Organizational commitment can also be described as a psychological emotional state that describes the employee's identification with the company.

Saridakis et al., (2020) Organizational commitment is defined as individual identification and involvement in work organizations in particular and includes individual acceptance of the goals and values of the organization, the desire to work hard for the organization together with different ambitions to continue working for the organization. Furthermore, according to Widodo et al., (2019) organizational commitment is an important dimension of behavior that can be used to assess the tendency of employees to stay as members of the organization. Commitment is the identification and connection of a person who is relatively strong in the organization. High organizational commitment has a different attitude than those with low commitment. Organizational commitment behavior results in work performance, low levels of absenteeism and low levels of employee turnover. 
Robbins \& Judge (2016) says organizational commitment is defined as a condition in which an employee sides with a particular organization and its goals, and intends to maintain membership in that organization. Furthermore, Robbins \& Judge (2016) also views organizational commitment as one of the work attitudes defined as an individual orientation towards the organization which includes loyalty, identification, and involvement, according to him, committed employees are less likely to withdraw jobs even if they are not. satisfied, because they have a sense of loyalty to the organization. The literature of organizational commitment was established three dimensions of organizational commitment, namely: (1) Affective Commitment, (2) Continuance Commitment and (3) Normative Commitment. Based on the introduction and literature review, the hypothesis formulation can be described as follows:

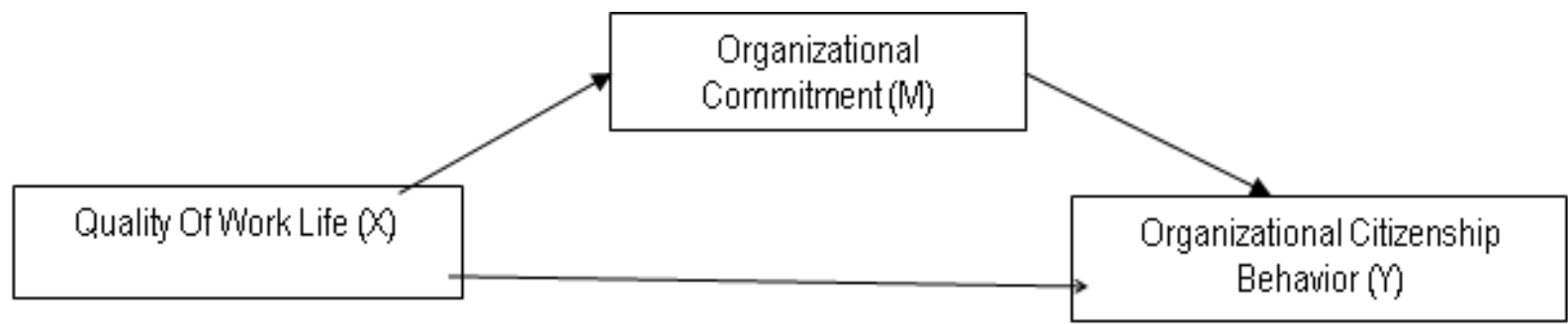

\section{Increasing \\ Organizational \\ Citizenship \\ Behavior Through \\ Quality of Work \\ Life and \\ Organizational \\ Commitment}

Figure 1.

Research

Framework

\section{Hypothesis Development}

From the research conceptual model, the following hypotheses can be formulated:

H1 : Quality of Work Life has a positive and significant effect on OCB

H2 : Quality of Work Life has a positive and significant effect on Organizational commitment.

H3 : Organizational Commitment has a positive and significant effect on OCB

H4 : Organizational Commitment mediates the relationship between QWL and OCB

\section{RESEARCH METHODOLOGY}

In this study, the population is 442 of the permanent employees who worked at PT. PetroChina International Jabung Ltd. If the population is less than 100 people, the total sample is taken, but if the population is greater than 100 people, $10-15 \%$ or $20-25 \%$ or more of the population can be taken (Arikunto, 2016). The sampling method used is Non-Probability Sampling with purposive sampling technique, which is a sampling technique with certain considerations and criteria (Saunders et al., 2016). This technique was chosen because researchers have their own considerations, by deliberately selecting members of the population who are considered to be able to provide information, where the selected respondents have terms and conditions, namely permanent employees and a minimum length of work over 5 years. The number of samples in this study were 120 respondents. The data collection method uses a questionnaire on line method which is measured using a Likert scale of 1 to 7 . The hypotheses was tested using PLS (Partial Least Square) method with the smartPLS program.

\section{RESULTS}

\section{Evaluation of the Measurement Model (Outer Model)}

Convergent Validity Test

Convergent validity can be seen from the loading factor for each construct indicator. The rule of thumb used to assess convergent validity is that the loading factor value must be greater than 0.7 . There are two criteria for assessing the outer model that meets the convergent validity requirements for a reflective construct, namely (1) loading must be above 0.7 and (2) significant $p$ value $<0.05$ (Abdillah \& Jogiyanto 2016).

According to Ghozali \& Latan (2019) a questionnaire is declared valid if the AVE value $>0.5$. If the loading score is between $0.5-0.7$, the researcher should not delete the indicator that has the loading score as long as the AVE score and the indicator's communality $>0.5$ (Abdillah \& Hartono, 2015).

In this research, an indicator is declared valid if it has a loading factor above 0.7 for a targeted construct and AVE value $>0.5$. Tables 2 to 4 are the results of loading factor for question items for each variable after all initial data is entered into the SmartPLS program and run through the PLS Algoritm.

The first variable is Quality of Work Life which is formulated in 35 question indicators. The loading factor for the quality of work life variable can be seen in table 2 below: 
Table 2. Quality of Work Life Loading Factor

\begin{tabular}{|c|c|c|c|}
\hline Dimension & Indicator & Loading Factor & Result \\
\hline \multirow{3}{*}{ Work Environment Safety (X1) } & X.1.1 & 0,463 & invalid \\
\hline & $\mathrm{X} .1 .2$ & 0,172 & invalid \\
\hline & X.1.3 & 0,712 & Valid \\
\hline \multirow{4}{*}{ Balanced Compensation (X2) } & X.2.1 & 0,723 & Valid \\
\hline & X.2.2 & 0,641 & invalid \\
\hline & X.2.3 & 0,710 & Valid \\
\hline & X.2.4 & 0,748 & Valid \\
\hline \multirow{4}{*}{ Communication (X3) } & X.3.1 & 0,725 & Valid \\
\hline & X.3.2 & 0,800 & Valid \\
\hline & X.3.3 & 0,722 & Valid \\
\hline & X.3.4 & 0,824 & Valid \\
\hline \multirow{3}{*}{ Conflict resolution (X4) } & X.4.1 & 0,720 & Valid \\
\hline & $\mathrm{X} .4 .2$ & 0,771 & Valid \\
\hline & X.4.3 & 0,783 & Valid \\
\hline \multirow{5}{*}{ Career development (X5) } & $\mathrm{X.5.1}$ & 0,784 & Valid \\
\hline & X5.2 & 0,737 & Valid \\
\hline & X.5.3 & 0,663 & invalid \\
\hline & X.5.4 & 0,724 & Valid \\
\hline & $\mathrm{X} .5 .5$ & 0,701 & Valid \\
\hline \multirow{4}{*}{ Employee Participation (X6) } & X.6.1 & 0,778 & Valid \\
\hline & X.6.2 & 0,757 & Valid \\
\hline & X.6.3 & 0,762 & Valid \\
\hline & X.6.4 & 0,658 & invalid \\
\hline \multirow{4}{*}{ Job Security (X7) } & X.7.1 & 0,828 & Valid \\
\hline & X.7.2 & 0,699 & invalid \\
\hline & X.7.3 & 0,606 & invalid \\
\hline & X.7.4 & 0,757 & Valid \\
\hline \multirow{4}{*}{ Available Facilities (X8) } & X.8.1 & 0,714 & Valid \\
\hline & $\mathrm{X} .8 .2$ & 0,807 & Valid \\
\hline & X.8.3 & 0,749 & Valid \\
\hline & X.8.4 & 0,615 & invalid \\
\hline \multirow{4}{*}{ Pride in the institution (X9) } & X.9.1 & 0,689 & invalid \\
\hline & $\mathrm{X} .9 .2$ & 0,649 & invalid \\
\hline & $\mathrm{X} .9 .3$ & 0,780 & Valid \\
\hline & X.9.4 & 0,741 & Valid \\
\hline
\end{tabular}

Source: Results of SmartPLS 3.3.3 Data Processing

Based on the loading factor value in table 2 , it is found that there are 10 indicators that have a loading factor value $<0.7$. The ten indicators will be deleted because they cannot fulfill the construct validity in this research.

The second variable is Organizational Commitment which is formulated in 24 question indicators. Loading Factor for organizational commitment can be seen in table 3 below: 


\begin{tabular}{|c|c|c|c|}
\hline Dimension & Indicator & Loading Factor & Result \\
\hline \multirow{4}{*}{ Altruism (Y1) } & Y.1.1 & 0,731 & Valid \\
\hline & Y.1.2 & 0,585 & invalid \\
\hline & Y.1.3 & 0,712 & Valid \\
\hline & Y.1.4 & 0,653 & invalid \\
\hline \multirow{6}{*}{ Conscientiousness (Y2) } & Y.2.1 & 0,775 & Valid \\
\hline & Y.2.2 & 0,768 & Valid \\
\hline & Y.2.3 & 0,768 & Valid \\
\hline & Y.2.4 & 0,775 & Valid \\
\hline & Y.2.5 & 0,827 & Valid \\
\hline & Y.2.6 & 0,489 & invalid \\
\hline \multirow{5}{*}{ Sportmanship (Y3) } & Y.3.1 & 0,846 & Valid \\
\hline & Y.3.2 & 0,825 & Valid \\
\hline & Y.3.3 & 0,557 & invalid \\
\hline & Y.3.4 & 0,737 & Valid \\
\hline & Y.3.5 & 0,676 & invalid \\
\hline \multirow{4}{*}{ Courtesy (Y4) } & Y.4.1 & 0,797 & Valid \\
\hline & Y.4.2 & 0,628 & invalid \\
\hline & Y.4.3 & 0,823 & Valid \\
\hline & Y.4.4 & 0,682 & invalid \\
\hline \multirow{4}{*}{ Civic Virtue (Y5) } & $\begin{array}{l}\text { Y.5.1 } \\
\end{array}$ & 0,864 & Valid \\
\hline & Y.5.2 & 0,865 & Valid \\
\hline & Y.5.3 & 0,757 & Valid \\
\hline & Y.5.4 & 0,601 & invalid \\
\hline
\end{tabular}

Source: Results of SmartPLS 3.3.3 Data Processing

Based on the loading factor value in table 3 it is found that of the 24 (twenty four) indicators of organizational commitment questions, there are 12 (twelve) invalid question indicators because they have a loading factor value $<0.7$ so that the twelve indicators will be deleted because it cannot fulfill the construct validity in this research.

The third variable is organizational citizenship behavior which is formulated in 23 (twenty three) question indicators. Loading factors for OCB can be seen in table 4 below:

\begin{tabular}{|c|c|c|c|}
\hline Dimension & Indicator & Loading Factor & Result \\
\hline \multirow{4}{*}{ Altruism (Y1) } & Y.1.1 & 0,731 & Valid \\
\hline & Y.1.2 & 0,585 & invalid \\
\hline & Y.1.3 & 0,712 & Valid \\
\hline & Y.1.4 & 0,653 & invalid \\
\hline \multirow{6}{*}{ Conscientiousness (Y2) } & Y.2.1 & 0,775 & Valid \\
\hline & $\begin{array}{l}\text { Y.2.2 } \\
\end{array}$ & 0,768 & Valid \\
\hline & Y.2.3 & 0,768 & Valid \\
\hline & Y.2.4 & 0,775 & Valid \\
\hline & Y.2.5 & 0,827 & Valid \\
\hline & Y.2.6 & 0.489 & invalid \\
\hline \multirow{5}{*}{ Sportmanship (Y3) } & Y.3.1 & 0,846 & Valid \\
\hline & $\begin{array}{l}\text { Y.3.2 } \\
\end{array}$ & 0,825 & Valid \\
\hline & Y.3.3 & 0,557 & invalid \\
\hline & Y.3.4 & 0,737 & Valid \\
\hline & Y.3.5 & 0,676 & invalid \\
\hline \multirow{4}{*}{ Courtesy (Y4) } & Y.4.1 & 0,797 & Valid \\
\hline & Y.4.2 & 0,628 & invalid \\
\hline & Y.4.3 & 0,823 & Valid \\
\hline & Y.4.4 & 0,682 & invalid \\
\hline \multirow{4}{*}{ Civic Virtue (Y5) } & Y.5.1 & 0,864 & Valid \\
\hline & Y.5.2 & 0,865 & Valid \\
\hline & Y.5.3 & 0,757 & Valid \\
\hline & Y.5.4 & 0,601 & invalid \\
\hline
\end{tabular}

Table 4.

Organizational

Citizenship

Behavior Loading

Factor 
Table 5.

AVE Value in each Construct (Research Variable)

Table 6.

Measurement

Results of

Composite

Reliability and

Cronbach Alpha

Table 7.

Output $R$-Square
Based on the loading factor value in table 4, it is found that of the 23 (twenty three) indicators of organizational citizen behavior questions, there are 8 (eight) invalid question indicators because they have a loading factor value $<0.7$. The eight indicators will be deleted because they cannot fulfill the construct validity in this research.

\section{Discriminant Validity Test}

To assess discriminant validity using the Square root of AVE value for each construct. If the AVE value of each construct is greater than 0.50 , it is said that the construct has a good validity discriminant value. The AVE value for each construct can be seen in table 5 below:

\begin{tabular}{ccc}
\hline No & Construct & AVE \\
\hline 1 & Quality of Work Life $(\mathrm{X})$ & 0,598 \\
\hline $\mathbf{2}$ & Commitment Organization $(\mathrm{M})$ & 0,726 \\
\hline 3 & Organizational Citizenship behavior $(\mathrm{Y})$ & 0,670 \\
\hline
\end{tabular}

Source: Results of SmartPLS 3.3.3 Data Processing

Based on the AVE value of each construct in the table above, it shows that the value is greater than 0.50 , which means that each of these constructs has good discriminant validity.

\section{Reliability Test}

After measuring the convergent validity and measuring the discriminant validity, finally the internal reliability test was carried out which was measured by two criteria, namely composite reliability and Cronbach alpha from the indicator block measuring the variables. The construct is declared reliable if the composite reliability and Cronbach alpha value is above 0.70 (Ghozali and Latan, 2019).

\begin{tabular}{lcc}
\hline \multicolumn{1}{c}{ Variabel } & Composite Reliability & Cronbach Alpha \\
\hline Quality of Work Life (X) & 0,970 & 0,968 \\
\hline Commitment Organization (M) & 0,964 & 0,958 \\
\hline Organizational Citizenship behavior (Y) & 0,963 & 0,958 \\
\hline
\end{tabular}

Source: Results of SmartPLS 3.3.3 Data Processing

Based on the data table 6 shows the results of the composite reliability and Cronbach alpha output for each variable, the quality of work life, organizational commitment and organizational citizenship behavior are very reliable because they have a measurement value above 0.7 , meaning that the indicators of all variables are considered reliable to be used as research instrument. Based on the values of composite reliability in table 6 , it can be concluded that the actual data of this study meets the reliability test.

\section{Inner Model Evaluation}

Ghozali and Latan (2019) state that the inner model or structural model testing is carried out to see the relationship between constructs or latent variables seen from the R-Square of the research model.

\begin{tabular}{|l|c|c|}
\hline \multicolumn{1}{|c|}{ Construct Variables } & R-Square & R-Square Adjusted \\
\hline Commitment Organization & 0,606 & 0,602 \\
\hline $\begin{array}{l}\text { Organizational Citizenship } \\
\text { behavior }\end{array}$ & 0,513 & 0,504 \\
\hline
\end{tabular}

Source: Results of SmartPLS 3.3.3 Data Processing

The R-Square value from the results of the analysis using SmartPLS software, obtained a value of 0.513 to the dependent variable Organizational Citizenship Behavior. Thus it can be said that Organizational Citizenship Behavior can be explained by the Quality of Work Life and Organizational Commitment by 51\% while the rest, namely $49 \%$, is influenced by other variables that are not explained in this research. Meanwhile, the R-Square for the mediating variable of organizational commitment has a value of 0.606 . Thus it can be said that organizational commitment can be explained by the Quality of Work Life by $61 \%$, while the rest, which is $39 \%$, is influenced by other variables that cannot be explained in this research. 


\section{Direct Effect}

Hypothesis testing in this study is used to test the direct effect of the independent variable (X) on the dependent variable $(\mathrm{Y})$, and the effect of the independent variable $(\mathrm{X})$ on the dependent variable $(\mathrm{Y})$ after being mediated by the mediating variable $(\mathrm{M})$ by looking at the $\mathrm{t}$-values in each path. The calculated t value is obtained from the results of data processing using a procedure called bootstrap, SmartPLS version 3.3.3 can produce tstatistics of path coefficients (inner model) and t-statistics of outer loadings to test the significance of structural models and measurement models. To test the hypothesis, it can be seen from the magnitude of the p-value. If the $\mathrm{p}$-value is $\leq 0.05$, the variable relationship is significant. The following table is the result of SmartPLS 3.3.3 data processing.

\begin{tabular}{|l|r|r|r|r|r|l|}
\hline & $\begin{array}{c}\text { Original } \\
\text { Sample } \\
(\mathrm{O})\end{array}$ & $\begin{array}{c}\text { Sample } \\
\text { Mean (M) }\end{array}$ & $\begin{array}{c}\text { Standard } \\
\text { Deviation } \\
(\text { STDEV })\end{array}$ & $\begin{array}{c}\text { T Statistics } \\
(\mid \mathrm{O} / \text { STDEV })\end{array}$ & $\begin{array}{c}\text { P } \\
\text { Values }\end{array}$ & Information \\
\hline QWL -> OC & 0,778 & 0,784 & 0,038 & 20,257 & 0,000 & Accepted \\
\hline QWL -> OCB & 0,319 & 0,323 & 0,100 & 3,193 & 0,001 & Accepted \\
\hline OC -> OCB & 0,440 & 0,444 & 0,110 & 3,988 & 0,000 & Accepted \\
\hline
\end{tabular}

Path Coefficients

Testing Results

Source: Results of SmartPLS 3.3.3 Data Processing

\section{Indirect Effect}

Testing the indirect effect by involving the mediating variable can be seen from the comparison of the direct effect with the total effect (Ghozali and Latan, 2019). If the direct effect is smaller than the total effect, it is evident that the organizational commitment variable is a mediating variable or it can also be seen by the probability value, where if the $\mathrm{P}$-value is $<0.05$, the organizational commitment variable can mediate the influence between the quality of work life and organizational citizenship behavior.

\begin{tabular}{|l|c|c|c|c|c|c|}
\hline & $\begin{array}{c}\text { Original } \\
\text { Sample } \\
(\mathrm{O})\end{array}$ & $\begin{array}{c}\text { Sample } \\
\text { Mean } \\
(\mathrm{M})\end{array}$ & $\begin{array}{c}\text { Standard } \\
\text { Deviation } \\
(\text { STDEV })\end{array}$ & $\begin{array}{c}\text { T Statistics } \\
(|\mathrm{O} / \mathrm{STDEV}|)\end{array}$ & P Values & Information \\
\hline $\begin{array}{l}\text { QWL -> OC- } \\
>\text { OCB }\end{array}$ & 0,342 & 0,348 & 0,087 & 3,945 & 0,000 & Accepted \\
\hline
\end{tabular}

Table 9.

Total Indirect

Effect

The results show that the influence between the quality of work life on organizational citizenship behavior results in a path coefficient value of 0.342 and a T-statistic value of $3.945(\mathrm{t}>1.96)$ with a significance level of $p$-value $=0.000(p$-value $<0.05)$. These results indicate that the influence of the quality of work life on organizational citizenship behavior mediated by organizational commitment is positive and significant, so that hypothesis 4 (H4) accepted

\section{Mediation Effect}

According to Sholihin dan Ratmono (2013) the mediation testing procedure in SEM-PLS with the variance accounted for (VAF) method as follows:

a) The direct effect $(\mathrm{X} \rightarrow \mathrm{Y})$ when the mediating variable has not been included must be significant. It is known that the path coefficient of the quality of work life on organizational citizenship behavior before being mediated by organizational commitment is 0.319 with p-value 0.001 (significant).

b) The indirect effect of $\mathrm{X} \rightarrow \mathrm{M}$ then $\mathrm{M} \rightarrow \mathrm{Y}$ after the mediating variable is entered into the model must be significant. It is known that the path coefficient of the quality of work life to organizational commitment is 0.778 with p-value 0.000 (significant) then the path coefficient of organizational commitment to organizational citizenship behavior is 0.440 with $\mathrm{p}$-value 0.000 (significant).

c) It is known that the direct effect of $\mathrm{X} \rightarrow \mathrm{Y}$ (significant) and the indirect effect of $\mathrm{X} \rightarrow \mathrm{M}$ (significant) then $\mathrm{M}$ $\rightarrow$ Y (significant), so this condition fulfills the procedure in mediation testing in SEM-PLS with the variance accounted for (VAF) method.

The following table show the VAF calculation 
AMBR

Table 10.

Variance

Accounted For

(VAF) Calculation

\begin{tabular}{|l|r|}
\hline \multicolumn{1}{|c|}{ Influence Description } & \multicolumn{1}{|c|}{ The calculation results } \\
\hline Indirect Effect & $0,778 * 0,440$ \\
$\mathbf{Q W L} \rightarrow \mathbf{C O M M I T M E N T}=\mathbf{0 , 7 7 8}$ & $=0,342$ \\
$\mathbf{C O M M I T M E N T ~} \rightarrow$ OCB $=\mathbf{0 , 4 4 0}$ & 0,319 \\
\hline $\begin{array}{l}\text { Direct Effect } \\
\text { QWL } \rightarrow \text { OCB }=\mathbf{0 , 3 1 9}\end{array}$ & $0,342+0,319$ \\
\hline Total Effect & $=0,661$ \\
\hline $\begin{array}{l}\text { Variance Accounted For }(\boldsymbol{V A F}) \\
\text { Indirect Effect/ Total Effect }\end{array}$ & $0,342 / 0,661$ \\
\hline
\end{tabular}

Source: Primary data processed in (2021)

From the calculation of table 10 above, it can be seen that the calculation results of the variance accounted for (VAF) table are $51.7 \%$. The VAF value is greater than $20 \%$ but less than $80 \%$, this indicates that the variable organizational commitment as a partial mediation influences the quality of work life on organizational citizenship behavior (OCB), which means that the quality of work life in part has a direct effect on organizational citizenship behavior (OCB) of employees and partially mediated by organizational commitment.

\section{DISCUSSION}

The first finding of this study show the positive correlation coefficient. It indicates that the higher the quality of work life, the higher the employee's OCB, vice versa. This finding is in line with Kurniawati (2018) which concluded that the quality of work life has a significant effect on the OCB. Kurniawati (2018) also explained that in an organization the quality of work life is very important to be considered as a supporter of the OCB, because employees who have high quality of work life will encourage actions taken by employees that exceed the minimum requirements expected by the role of the organization. With the implementation of good quality of work life in the organization, it is expected that it will be able to encourage the behavior of the employees of the employee organization in the organization. This confirms that the quality of work life has become a necessity for organizations out of necessity (Duyan, Serpil, Neslihan and Darren, 2013).

The results of this study are also supported by the results of research conducted by Pio \& Lengkong (2020) ; Ojo et al., (2020) and Wibowo et al., (2020) which revealed that the Quality of Work Life has a significant effect on the organizational citizenship behavior. According to Susanti (2015) in developing organizational citizenship behavior, it also requires the creation of good quality of work life. Employees who have a high quality of work life will encourage the emergence of organizational citizenship behavior in employees, because they have a greater possibility to speak positively about the organization, willingness to help others and do work to exceed what the organization expects. This contribution indicates that the variable quality of work life has an important role in shaping employee organizational citizenship behavior (OCB).

The second finding of this this study indicate a positive and significant influence between the quality of work life and organizational commitment. Quality of work life is a process in which organizations respond to employee needs by developing mechanisms to allow employees to give full contribution and participate in making decisions and regulating their work life in a company. Quality of work life for employees is one of the important goals in meeting the needs and desires of employees. Quality of work life is the employee's perception of his physical and well-being at work. There are two views as to what the quality of work life means. First, the quality of work life is a number of circumstances and practices of the organization (eg worker involvement, comfortable working conditions, and career development). While the second, the quality of work life is the perception of employees that they want to feel safe, they feel satisfied, and get the opportunity to grow and develop as human beings.

Quality of work life as a management system approach to coordinating and linking the potential of human resources in the organization, as an effort by the leadership to meet the needs of members and organizations simultaneously and continuously. Quality of work life is a form of philosophy applied by management in managing organizations in general and human resources in particular. As a philosophy, the quality of work life is a management perspective on people, workers and organizations. The findings in this study indicate that the quality of work life has a positive and significant effect on organizational commitment. This means that changes in organizational commitment by employees are influenced by the quality of work life. In line with the research conducted by Agus \& Selvaraj (2020) that employee commitment partially mediates the relationship between the quality of work life and the intention to stay. In conclusion, if employees are satisfied with the quality of their work life, the stronger the employee's commitment to being in the organization and ultimately their intention to stay. 
The same research was also conducted by Pramudena (2019) ; Akar (2018) and Farid et al., (2015) which show that the variable quality of work life has a positive and significant effect on organizational commitment. With a good quality of work life, employee commitment will increase. Employees who value the achievement of the quality of work life will give more commitment in return for the organization.

The third finding of this study indicate a positive and significant influence between organizational commitment and organizational citizenship behavior. It means that the higher the organizational commitment of the employees, the higher the organizational citizenship behavior of employees. It shows that employees who have organizational commitment will do not only tasks that have become their obligations but will voluntarily do things that are extra efforts, high dedication to the company and a level of sacrifice to existing work, support and comply with every policy issued by the workplace, accept every policy, regulation and procedure established by the company and there is high loyalty to the company so that it will foster the organizational citizenship behavior in itself.

This research is supported by Vincent Obedgiu \& Vincent Bagire (2017) ; Zayas-Ortiz, M., Rosario, E., Marquez, E., \& Gruñeiro (2015) ; Sumiati et al., (2018) ; Wibawa (2019) ; Nurwadi \& Ardana (2019) and Biswan (2019) who prove that organizational commitment has significant effect on the organizational citizenship behavior where employees with high organizational commitment will have a positive impact at work, by giving their best efforts to carry out their duties.

The fourth findings indicate that organizational commitment mediates the effect of the quality of work life on the organizational citizenship behavior of employees The mediation testing shows that this model is a partial mediation, which means the affects of quality of work life to the organizational citizenship behavior not only directly, but also indirectly through organizational commitment as mediators.

This result means that the implementation of the quality of work life can optimally foster OCB if the PetroChina Company increases organizational commitment of employees. Moreover, it is supported by the optimal application of the 9 dimensions of quality of work life as stated by Cascio (2003) and Avianti \& Kartika (2017). Increasing QWL is very supportive in creating and encouraging the formation of employee OCB behavior and this is done in order to streamline and develop the organization. Organizational commitment has an important role in mediating the effect of quality of work life on the organizational citizenship behavior, employees who have high organizational commitment will have loyalty, doing work not only tasks that have become their obligations, but will voluntarily do things that can be classified. As an extra effort, the quality of work life is seen as being able to increase the participation and contribution of employees to the company, the quality of work life is a level where members of an organization are able to satisfy important personal needs through their experience in doing work for the company.

This study supports the study of Chrisienty (2015) which shows that the quality of work life has a positive effect on employee organizational commitment. The quality of work life can be said to be a concept that seeks to condition the work environment in the company optimally so that each employee is able to mobilize all the ability it has. In addition, employees who have organizational commitment will do work that is not only in accordance with existing jobs, but also perform other jobs (extra roles), this extra-role behavior is also known as Organizational Citizenship Behavior (Gunastri et al., 2019).

This finding is also in line with research conducted by Akar (2018). His finding show that someone who is committed to his organization will often display OCB which will support organizational success. This research also shows that it turns out that organizational commitment is a factor that strengthens the mediating effect of the quality of work life on the organizational citizenship behavior. The OCB are influenced by several motives, including commitment to the organization where there is a desire to participate well in the organization and pride to be part of the organization, this includes ways of developing goals or meeting organizational needs which essentially put the mission of the organization ahead of personal interests (Wahyuni and Supartha, 2019),

\section{CONCLUSIONS}

Quality of work life has positive and significant effect on the organizational citizenship behavior. This means that the better of the implementation of quality work life programs, the higher the employee's OCB level. Quality of work life also has positive and significant effect on employee organizational commitment. This means that with good quality of work life, employee commitment will increase.

Organizational commitment has positive and significant effect on the organizational citizenship behavior. This imply to increase OCB can be conducted by increasing the organizational commitment directly.Indirectly, through the increasing of quality of work life and then organizational commitment. 
Abdillah, Willy., \& J. H. (2016). Partial Least Square (PLS) Alternatif Structural Equation Modeling (SEM) dalam Penelitian Bisnis (1st ed.). Yogyakarta: ANDI.

Agus, A., \& Selvaraj, R. (2020). The mediating role of employee commitment in the relationship between quality of work life and the intention to stay. Employee Relations, 42(6), 1231-1248. https://doi.org/10.1108/ER-072019-0292

Aini, F. A., Hardjajani, T., \& Priyatama, A. N. (2014). Hubungan antara kualitas interaksi atasan dan bawahan. Wacana Jurnal Psikologi, 6(11): 55-.

Aisyah, L. N., \& Wartini, S. (2016). Pengaruh Kepemimpinan Transformasional dan Kualitas Kehidupan Kehidupan Kerja Pada Organizational Citizenship Behavior (OCB) Melalui Komitmen Organisasional. Management Analysis Journal, 5(3), 229-243.

Akar, H. (2018). The relationships between quality of work life, school alienation, burnout, affective commitment and organizational citizenship: A study on teachers. European Journal of Educational Research, 7(2), 169_ 181. https://doi.org/10.12973/eu-jer.7.2.169

Arikunto, S. (2016). Prosedur Penelitian Suatu Pendekatan Praktik. Jakarta: Rineka Cipta.

Avianti, D. A., \& Kartika, L. (2017). Analisis Quality Of Work Life Pada Generasi X Dan Y Alumni Fakultas Ekonomi dan Manajemen IPB. Jurnal Riset Manajemen Dan Bisnis (JRMB) Fakultas Ekonomi UNIAT. https://doi.org/10.36226/jrmb.v2i2.40

Belwalkar, S., Vohra, V., \& Pandey, A. (2018). The Relationship between Workplace Spirituality, Job Satisfaction and Organizational Citizenship Behaviors - An Empirical Study. In Social Responsibility Journal (Vol. 13, Issue 1).

Biswan, A. T. (2019). Peran Mediasi Motivasi Kerja Pada Pengaruh Kecerdasan Emosional Dan Komitmen Organisasi Terhadap Organizational Citizenship Behavior Pegawai Pemerintah. Matrik : Jurnal Manajemen, Strategi Bisnis Dan Kewirausahaan, 13(2), 204. https://doi.org/10.24843/matrik:jmbk.2019.v13.i02.p08

Cascio, W. F. (2003). Managing Human Resources: Productivity, Quality of WorkLife, Profits: Vol. (6th ed).

Chrisienty, W. (2015). Pengaruh Quality Of Work Life terhadap Komitmen Organisasional Karyawan” di CV Sinar Plasindo. Program Manajemen Bisnis, Program Studi Manajemen, Universitas Kristen Petra Jl. Siwalankerto 121-131, Surabaya. AGORA, 3, No. 2.

Duyan, Emin Cihan., Serpil Aytaç, N. A. and D. V. L. (2013). Measuring Work Related Quality of Life and Affective Well- Being in Turkey. Mediterranean Journal of Social Sciences, ISSN 2039-.

Farid, H., Izadi, Z., Ismail, I. A., \& Alipour, F. (2015). Relationship between quality of work life and organizational commitment among lecturers in a Malaysian public research university. Social Science Journal, 52(1), 54-61. https://doi.org/10.1016/j.soscij.2014.09.003

Ghozali, I., \& Latan, H. (2019). Partial Least Squares. Konsep, Teknik dan Aplikasi menggunakan Program SmartPLS 3.0 Untuk Penelitian Empiris (2nd ed.). Universitas Diponegoro Semarang.

Golkar, H. (2013). The relationship between qwl and job satisfaction : a survey of human resource managers in Iran. Interdiciplinary Journal of Contemporary Research In Business, 5 No. 8, 215-224.

Gunastri, Ni Made., A.A. Istri Ratna Eka Handayani \& I Made Purba Astakoni. (2019). Analisis Pengaruh Kepuasan Kerja Terhadap Organizational Citizenship Behavior (OCB) dengan Variabel Mediasi Komitmen Organisasional (Studi Pada Koperasi Asadana Semesta Denpasar). 14. No. 1.(28 Februari 2019, ISSN 19786069).

Hair, J. F. Jr., Black, W. C., Babin, B. J. and Anderson, R. E. (2014). Multivariate Data Analysis (7th Edition).

Hermawati, A., \& Mas, N. (2016). Quality Of Work Life Dan Organizational Citizenship Behavior Sebuah Kajian Empiris. Badan Penerbitan Universitas Widyagama Malang.

Kurniawati, C. E. (2018). Pengaruh Quality Of Work Life terhadap Work Engagment dengan Organizational Citizenship Behavior pada Perusahaan Elektronik di Surabaya. Manajemen Bisnis, Program Studi Manajemen, Fakultas Ekonomi, Universitas Kristen Petra. AGORA, 6 No. 2.

Maghfironsyah, F.A., dan Yuniawan, A. (2019). Analisis Hubungan Big Five Personality dan Komitmen Organisasi Serta Pengaruhnya Terhadap Organizational Citizenship Behavior (Studi Pada Karyawan Dinas Kesehatan Kota Salatiga). Diponegoro Journal of Management, 8 No.4, 1-14. 
Marlina, E., Wulandari, N., \& Ramashar, W. (2020). Peran Organizational Citizenship Behavior pada Pengaruh Budaya Organisasi dan Komitmen Organisasi Terhadap Kinerja Karyawan SKK Migas. Muhammadiyah Riau Accounting and Business Journal, 2(1), 127-137. https://doi.org/10.37859/mrabj.v2i1.2131

Mebarki, B., Fouatih, M.E.A.A. and Mokdad, M. (2018). Quality of work life and differences in demographic characteristics among managerial staff in Algerian tertiary sector. Congress of the International Ergonomics Association, Springer, Cham, 220-232.

Novelia, M., B. S. dan I. R. (2016). Pengaruh Komitmen dan Organizational Citizenship Behavior (OCB) Terhadap Kinerja” (Studi Pada Tenaga Keperawatan Rumah Sakit Umum Daerah dr. Soegiri Lamongan). Jurnal Administrasi Bisnis (JAB), 38, No.2.

Nurwadi, V. K., \& Ardana, I. K. (2019). Peran Komitmen Organisasi Dalam Memediasi Pengaruh Organizational Justice Terhadap Organizational Citizenship Behavior (Studi Pada Sopir Taksi Blue Bird Group Jimbaran). E-Jurnal Manajemen, 8(10), 6219-6241.

Ojo, S., Zaccheaus O., O., \& Luqman, B. (2020). Influence of Quality of Work-Life on Organizational Citizenship Behaviour: A Case Study of Selected Ministries in State Secretariat, Abere, Osogbo, Osun State, Nigeria. World Journal of Business and Management, 6(1), 87. https://doi.org/10.5296/wjbm.v6i1.17288

Pio, R. J., \& Lengkong, F. D. J. (2020). The relationship between spiritual leadership to quality of work life and ethical behavior and its implication to increasing the organizational citizenship behavior. Journal of Management Development, 39(3), 293-305. https://doi.org/10.1108/JMD-07-2018-0186

Pramudena, S. M. (2019). The effect of quality of worklife and job satisfaction on organizational commitment. The Management Journal of Binaniaga, 4(1), 23. https://doi.org/10.33062/mjb.v4i1.351

Prasetio, A. P. (2016). Pengaruh Work Life Balance Terhadap Organizational Citizenship Behavior dengan Variabel Mediasi Kepuasan Kerja dan Komitmen Organisasi” pada Bank Rakyat Indonesia Kantor Wilayah Bandung. Universitas Pendidikan Indonesia, Repository.Upi.Edu.

Putra, D. S., Susilo, H., dan Aini, E. K. (2018). Pengaruh Budaya Organisasi Terhadap Organizational Citizenship Behavior (OCB) Dengan Kepuasan Kerja Sebagai Variabel Intervening (Studi Pada Karyawan Kusuma Agrowisata Divisi Hotel Kota Batu). Jurnal Administrasi Bisnis, 62(2), 28-36.

Rahman, A. (2017). Kualitas Kehidupan Kerja - Suatu Tinjauan Literatur dan Pandangan dalam Konsep Islam. Jurnal Ilmiah Cano Ekonomos, 6(1), 7-22.

Ritfy, N. I., \& Witjaksono, A. D. (2014). Pengaruh Kualitas Kehidupan Kerja Terhadap Komitmen Organisasi. Jurnal Ilmu Manejmen |, 2, 1080-1094.

Robbins, S. P., \& Judge, T. A. (2016). Organizational Behavior 17th Edition. London: Pearson Education.

Rosario Núñez, A., Marquez, E., Zayas, M., \& López, E. (2020). Relationship between organizational citizenship and commitment in Puerto Rico banks. International Journal of Sociology and Social Policy, 40(7-8), 643658. https://doi.org/10.1108/IJSSP-02-2020-0028

Saepudin, Ujang., S. P. D. (2019). Pengaruh Kepuasan Kerja Terhadap Organizational Citizenship Behavior (OCB) Guru dengan Komitmen Organisasional Sebagai Variabel Mediasi. Jurnal Ilmiah Bisnis, Pasar Modal, Dan UMKM, 2, No.1.

Saghi, Somaye K., Rezae Far, H., Zabihi, M., \& Hosseinpou, M. (2015). A Survey of the Mediation Role of Quality of Work Life in the Impact of Organizational Justice on Organizational Citizenship Behavior of Administrative Units in Azad University of Mashhad. Journal of Social Issues \& Humanities. 3(5): 1-7.

Sarhan, Nael., Ayman Harb, F. S. and M. A. (2019). The effect of organizational culture on the organizational commitment: Evidence from hotel industry. Management Science Letters 10, 183-196. Growing Science, Canada.

Saridakis, G., Lai, Y., Muñoz Torres, R. I., \& Gourlay, S. (2020). Exploring the relationship between job satisfaction and organizational commitment: an instrumental variable approach. International Journal of Human Resource Management, 31(13), 1739-1769. https://doi.org/10.1080/09585192.2017.1423100

Saunders, Mark., Lewis, Philip., Thornhill, A. (2016). Research Methods for Business Students.

Shahin, Arash., J. S. N. and J. K. P. (2014). Developing a model for the influence of perceived organizational climate on organizational citizenship behaviour and organizational performance based on balanced score card. International Journal of Productivity and Performance Management. Emerald Group Publishing Limited 1741-0401, 63(3), $290-307$. 
Sholihin, Mahfud dan Ratmono, D. (2013). Analisis SEM-PLS dengan Warp PLS 3.0 Untuk Hubungan Nonlinier Dalam Penelitian Sodial dan Bisnis. Andi Offset Sumarwan.

Srivastava, S., Misra, R. and Madan, P. (2019). The saviors are also humans': understanding the role of quality of work life on job burnout and job satisfaction relationship of Indian doctors. Journal of Health Management, 21 No. 2 ,

Sumiati, Ardiana, I. D. ketut R., \& Pratiwi, A. I. (2018). Pengaruh Komitmen Organisasi, Quality of Work Life (QWL) Terhadap Organizational Citizenship Behavior (OCB) dan Kinerja Pegawai Pada Dinas Kependudukan dan Pencatatan Sipil Kabupaten Bangkalan Madura Jawa Timur. JMM17 Jurnal Ilmu Ekonomi \& Manajemen, 05(01), 24-36.

Suriyana, N., Wijaya, R. A., \& Kumbara, V. B. (2020). Pengaruh Tingkat Quality Of Work Life (Qwl), Dan Knowledge Management Terhadap Organizing Citizenship Behavior (OCB) Dengan Kepuasan Kerja Sebagai Variabel Intervening Pada PT. Graindo Mediatama. Jmpis, 1(2), 548-559. https://doi.org/10.38035/JMPIS

Susanti, R. (2015). Hubungan Religiusitas dan Kualitas Kehidupan Kerja dengan Organizational Citizenship Behavior (OCB) Pada Karyawan. Jurnal Psikologi, 11 No. 02, 94-102.

Syahbanuari, B. A., \& Abdurrahman, D. (2019). Pengaruh Quality of Work Life (QWL) dan Komitmen Organisasi terhadap Organizational Citizenship Behavior (OCB) (Studi pada Pegawai Tetap PT Pindad PERSERO

Prosiding

Manajemen,

ISSN :

246. http://karyailmiah.unisba.ac.id/index.php/manajemen/article/view/14699.

Tambe, S \& Shanker, D. M. (2014). A Study of Organizational Citizenship Behaviour (OCB) and It's Dimensions: A Literature Review. International Research Journal of Business and Management.

Traiyotee, P., Taeporamaysamai, P., \& Saksamrit, N. (2019). Quality of work life affecting on organizational commitment through organizational behaviour : A case of PT Gas Service Station employees in northeast, Thailand. International Academic Research Conference, 267-272.

Vincent Obedgiu, Vincent Bagire, S. M. (2017). Examination of organizational commitment and organizational citizenship behavior among local government civil servants in Uganda. Journal of Hospitality and Tourism Technology, 8(1), 133-147.

Wahyuni, Ni Putu Devi Erlina., dan I. W. G. S. (2019). Pengaruh Keadilan Organisasional, Komitmen Organisasional, dan Kepuasan Kerja terhadap Organizational Citizenship Behavior (OCB). E-Jurnal Manajemen, Vol. 8, No. 10, ISSN : 2302-8912.

Wibawa, I Nyoman Bayu Putra Mahardika; I Made Artha. (2019). Pengaruh Budaya Organisasi Kepuasan Kerja dan Komitmen Organisasional Terhadap Organizational Citizenship Behavior Pada Karyawan. 8(1), 7340 7370 .

Wibowo, Nadia Tri Hastuti dan Ugung Dwi Ario. (2020). Pengaruh Quality Of Work Life (QWL) Dan Organizational Commitment (OC) terhadap Organizational Citizenship Behavior (OCB) Pada Perawat Tetap. $1(1), 1-9$.

Widodo, A., Sunaryo, H., dan K. (2019). Pengaruh Kecerdasan Emosional, Komitmen Organisasional, dan Organizational Citizenship Behavior Terhadap Kinerja Karyawan PT. Bank Muamalat Cabang Malang. EJurnal Riset Manajemen, 8 No.7, 47-60.

Zayas-Ortiz, M., Rosario, E., Marquez, E., \& Gruñeiro, P. C. (2015). Relationship Between Organizational Commitments and Organizational Citizenship Behaviour in a Sample of Private Banking Employees. International Journal of Sociology and Social Policy, Vol. 35, No. 1/2, 91-106. 